\title{
Online Learning Communities: Motivational Factors for Success
}

\author{
http://dx.doi.org/10.3991/ijes.v2i2.3812 \\ S.M. Paterson \\ University of Aberdeen, School of Education, Aberdeen, Scotland
}

\begin{abstract}
As the number of online programmes on offer in higher educational settings, continue to increase, there is a wealth of research evidence which highlights the benefits to be gained from teaching and learning through virtual learning environments and online communities. Past reports on the positive influence online communities have on both socialization and learning outcomes recognizes the value of such work. Yet many questions remain on the viability and veracity of online learning, particularly from the learner perspective. This study seeks to gain insights into learners' perceptions of online learning. Fifty (50) participant teachers, currently undertaking online modules as part of their Postgraduate Masters of Education programme in one Teacher Educational Institution in Scotland, were surveyed to ascertain and identify factors which they believed made working online successful and their perceived barriers to success as based on their range of online learning experiences. Feedback related to how motivated these students felt in their online work place. Results of the study indicated that most learners valued independence and ownership of working practices; the importance of tutor support and meaningful relevant materials; the need for easy module access and design including helpful time frames; the relevance of sharing professional practice in an online community and sited these reasons for the success of their online learning experience and therefore motivating. Participants indicated the barriers to successful online working to be problems with self motivation; difficulties in coping with technical problems and professional time constraints; anxiety with a lack of personal contact and a sense of frustration, when certain students did not always contribute to the work of the online community.
\end{abstract}

Index Terms-Barriers to learning, Distance learning, Motivational factors, Online learning.

\section{INTRODUCTION}

From the learner perspective, what makes working within online learning environments successful and how can understanding of this help motivate students working within virtual communities? What are the perceived barriers or challenges to effective learning and teaching in this way? Answers to these questions, among others, are gaining an increasing importance as Internet technologies become more readily available and accessible, in formal and informal contexts ${ }^{[1]}$. Hofmann (2002). The number of students being exposed to online working in Higher Educational Settings is on the increase. The University of Illinois for example, admitted over 1,000 students to online programmes from various states and foreign countries by the close of $2002^{[2] . ~ S a n t o v e c ~(2003) . ~ M a n y ~ u n i-~}$ versities worldwide are now offering entire degree programs online across a range of subjects. In addition to programs and courses, most universities students now require access to basic course information on line ${ }^{[3]}$. Leonard and Guha (2001). There is an expectation that, as a minimum, web based course administrative information will be available online.

As the ICT skills base of undergraduate students build with time there is an increased demand for new ways of learning through the development of virtual learning environments. Steadily more practicing teachers are returning to Higher Education, on a part time basis, to boost skills and qualifications and are themselves partaking in learning in such ways.

The imminent introduction of the world's first and largest educational intranet (*Glow) into Scottish schools brings with it a new way of working for teachers in schools and introduces them for the first time to working with their pupils through such virtual learning communities. An incentive has been provided therefore to investigate the answers to the above questions in a Higher Education setting and to share findings locally with colleagues in the primary and secondary educational sectors and with those in the academic field.

Although the increasing online access to programs, modules, and course information is exciting few studies have detailed the learners' perspectives of online learning. Online courses are designed and implemented in response to the constant growth of the web. This may of course also change the students' perceptions of their online experience.

In this study, in the main, it is hoped to explore the learners' views of what makes learning online successful and motivational. The researcher sought to investigate perceptions of the factors which contributed to participant's successful learning and communication and what specifically did not and what had therefore brought them to the programme being studied. The sample under investigation focuses on practicing teachers from the secondary sector of education in Scotland working at a distance for postgraduate certification. The study begins with a review of the literature related to online learning, considers the methodology used followed by a discussion of the findings. Finally, implications and suggestions for further research are presented.

\section{LITERATURE REVIEW}

The literature related to online learning has expanded considerably in the last 10-15 years. The review that follows focuses on literature related to the learner's experience, particularly the learners' perspectives of motivational strengths and weaknesses related to online learning. 


\section{A. Perceived strengths of online learning}

Few studies have explored learners' perspectives of online learning particularly in terms of perceived strengths and weaknesses pertaining to the online experiences which motivate and limit student participation. The convenience of when students were able to work online and post messages to each other was an advantage identified in the literature. For example, in [4]. Poole's (2000) study of student participation in a discussion-oriented online course, the results indicated that students participated in online discussions at times most convenient to them, such as evenings and weekends. Poole also found that students mostly accessed course materials from their home computers, the place most expedient to them. Similar results have been found by other researchers in their study of communication conventions in instructional electronic chats. Participants indicated they read and responded to comments in online discussions at times convenient to them - early/morning/ late/evening and ${ }^{[5] . ~ R o v a i ~(2001) ~}$ reported that online learners took advantage of the 'learn anytime' characteristics of the Internet.

Time to reflect and reply to messages also appeared to be important. In ${ }^{[6] .}$ Vonderwell's (2003) study, the author interviewed 22 students in regards to their perceptions of their asynchronous online learning experiences. Some participants expressed that the asynchronous environment allowed them to write carefully about their ideas. For example, one participant stated: "the discussion questions were not just for writing the answers; they required reflection" [6]. Vonderwell (2003 p.86). In a study done by ${ }^{[7] .}$ Petrides (2002), he interviewed learners to obtain their perspectives on online learning. His investigation focused on a class in a higher education setting which regularly met and in addition used online technology as a supplement. When interviewed, some participants indicated that they tended to think more deeply about the subject areas when responding in writing in the set asynchronous discussion spaces as compared to giving verbal responses. They explained that they were able to continually reflect upon each other's thoughts because of the public and permanent display of the discussion postings. One participant stated: "There is something that forces you to think more deeply about subject areas when you have to respond in writing" [7]. Petrides (2002, p.72). Another participant supported this, indicating that the online learning environment allowed more reflection than might occur for some individuals in face-to-face classroom discussions. Other research studies reported similar findings to those of [7]. Petrides' (2002) and ${ }^{[6] .}$ Vonderwell's (2003), reporting participants' perspectives that thoughtful and responsible comments are fostered by asynchronous online technologies. ${ }^{[8]}$ Chizmar and Walbert (1999) found that the public display of online discussions made learners more careful in posting their comments. Participants indicated there were several reasons for the careful posting, with one of the primary factors being that they knew it was there for the entire class, and indeed the world, to read ${ }^{[8]}$ Chizmar and Walbert (1999). Having one easily accessible work place is another reported strength of online learning. ${ }^{[7] .}$ Petrides (2002); ${ }^{[9]}$.Schrum (2002) stated that "participants reported it was easier to work in collaborative groups in an online course without rearranging everyone's plans as one might do in a traditional face-to-face course." In addition to access with time, choices related to the learning experience were also reported as positive. Participants in the ${ }^{[8] .}$ Chizmar and Walbert (1999) study indicated that the ability to freely pick and choose from the menu of diverse learning experiences enabled them to find the approaches that best fit the way they learn.

\section{B. Perceived weaknesses of online learning}

Several weaknesses, and therefore barriers, relating to online learning were also described in the literature. Difficulties with a sense of community and or feelings of isolation were among the barriers and challenges learners reported in their online learning experiences. In the large scale factor analytical study $(\mathrm{n}=1,056)$ carried out by ${ }^{[\mathrm{P}]}$. Muilenburg and Berge (2005), social interactions featured highly among the 8 barriers identified. [6]. Vonderwell (2003) reported that online learning participants indicated a lack of connection with the tutor, especially 'one-onone' relationship with the tutor. As stated by one participant in the study, "I still feel like I know a little bit about my tutor, but not the same way that I would if I was in a face to face situation. I don't know much about their personality at all" Other studies found similar results. For example, ${ }^{[11] .}$ Woods' (2002) reported that online learners reported feeling isolated from the university system as well as other learners in the online courses they had taken. A perceived level of expertise of peers is another weakness identified in online learning studies and may be related to the lack of formation of a true sharing online learning community. Participants in [7]. Petrides' (2002) study reported skepticism of their peers' supposed expertise. In contrast, the participants indicated they felt comfortable relying on the tutor's expertise. Response time from the tutor also caused angst. For example, in [6]. Vonderwell's (2003) study, one reported disadvantage of an online course was the delay of immediate feedback from the tutor. One participant in the study stated that when he emailed a question to the instructor, "it might take hours, maybe a day or so before you get an answer back for the question" [6]. Vonderwell, (2003, p.84). General unhappiness with the delay in responses from fellow participants

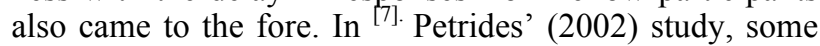
participants reported they felt a lack of immediacy in responses in the online context in comparison to what could typically occur in a structured face-to-face class discussion. This appears to be especially obvious in asynchronous online discussions when students have to wait for others to read and respond back to their discussion board postings or e-mail messages.

\section{RESEARCH QUESTION AND METHOD}

The purpose of this study was to investigate the factors which participants recognize as helpful and motivational in the virtual learning process and which contributed to successful learning in online learning environments and those that learners identified as challenging, demotivational and therefore causing barriers.

Two primary research questions guided this research:

- What are the factors for successful working in online learning environments as recognized as helpful and motivational in the learning process?

- What are the barriers of online learning environments that learners identified as challenging?

\section{A. Sample}

The participants in the study sample were drawn from practicing secondary teachers who worked on online 
modules as part of a post graduate programme which sits within the Masters in Education provision in an Initial Teacher Education institution in Scotland. Eighty learners (80) on this programme were contacted by e-mail by the Programme Secretary and asked to voluntarily participate in this study. Only she knew the identity of the participants who were thereafter referred to by individual number. A questionnaire was issued electronically which also asked learners to provide additional contact information if they were willing to participate further in a telephone interview. Fifty participants $(n=50)$ responded to the questionnaire $(62.5 \%)$ and respondees were asked to sign the standard research consent form. Thirty three participants volunteered to participate in the follow-up telephone interview.

The researcher interviewed participants on an individual basis to gather more in-depth information. All the participants in the study had taken at least one module which was delivered purely online and most had experienced face to face teaching with the same tutor team. Forty $(80 \%)$ of the surveyed participants had taken more than one online module and ten $(20 \%)$ were first-time online learners. All of the participants were aged from 20 to 50 and were classed as midterm educational professionals within the secondary sector. There were forty one $(82 \%)$ females and nine (18\%) males in the sample.

Of the thirty three participants interviewed, the following reasons were given for being initially drawn to the programme: it was recommended from a member of school staff i.e. Continual Professional Development coordinator, Head Teacher or Faculty Head (42\%), from the university or programme web site $(39 \%)$, through an information leaflet circulated within their school $(36 \%)$ or by personal recommendation from someone on the programme or who has done the programme (24\%).

The researcher ascertained the previous experiences and skills of the sample group before taking the online programme under investigation. Both in Information and Computing Technology (ICT) (Table 1) $(n=50)$ and the level to which participants had previously taken part in Continual Professional Development (CPD). (Table 2) $(\mathrm{n}=50)$.

For the purpose of this study, it was assumed that the participants were representative of online learners at the institution where the research was conducted and that they were generally representative of the learner population involved in an online learning environment at postgraduate level globally.

There were a few limitations associated with the research. One limitation was that the participants were determined by using purposeful sampling, with a focus on postgraduate students within a chosen programme. Generalization cannot be expected or assumed therefore. Another limitation relates to the validity and reliability of the survey. While the questionnaire is based on questions arising from the literature and was piloted prior to wide distribution, formal validity and reliability tests have not yet been performed.

\section{B. Data collection}

The study adopted mixed research methodology using both quantitative (predominately closed response questionnaire) and qualitative (interview) data collection methods. By using multiple sources for data collection,
TABLE I.

EXPERIENCE AND ICT SKILLS PRE-PROGRAMME.

\begin{tabular}{|l|l|l|l|}
\hline & Never & Sometimes & Often \\
\hline word process for personal use & $0 \%$ & $6 \%$ & $94 \%$ \\
\hline access the world wide web & $0 \%$ & $8 \%$ & $92 \%$ \\
\hline $\begin{array}{l}\text { send email messages for personal } \\
\text { purposes }\end{array}$ & $2 \%$ & $6 \%$ & $92 \%$ \\
\hline $\begin{array}{l}\text { send email messages for profes- } \\
\text { sional purposes }\end{array}$ & $6 \%$ & $10 \%$ & $84 \%$ \\
\hline search for online information & $2 \%$ & $8 \%$ & $90 \%$ \\
\hline $\begin{array}{l}\text { download files and resources } \\
\text { from the web }\end{array}$ & $4 \%$ & $16 \%$ & $80 \%$ \\
\hline $\begin{array}{l}\text { create a presentation (with e.g. } \\
\text { Power point }\end{array}$ & $14 \%$ & $26 \%$ & $60 \%$ \\
\hline take part in online discussions & $54 \%$ & $24 \%$ & $22 \%$ \\
\hline $\begin{array}{l}\text { share documents for group online } \\
\text { discussion }\end{array}$ & $64 \%$ & $20 \%$ & $16 \%$ \\
\hline add information to a web site & $76 \%$ & $6 \%$ & $18 \%$ \\
\hline create my own web site & $76 \%$ & $8 \%$ & $14 \%$ \\
\hline $\begin{array}{l}\text { host a web site chat room or } \\
\text { discussion }\end{array}$ & $78 \%$ & $12 \%$ & $6 \%$ \\
\hline study in an online learning course & $68 \%$ & $16 \%$ & $16 \%$ \\
\hline tutor in an online learning course & $94 \%$ & $2 \%$ & $4 \%$ \\
\hline $\begin{array}{l}\text { share professional information in } \\
\text { an online forum }\end{array}$ & $62 \%$ & $28 \%$ & $10 \%$ \\
\hline $\begin{array}{l}\text { publish materials on an educa- } \\
\text { tional web site }\end{array}$ & $82 \%$ & $8 \%$ & $6 \%$ \\
\hline $\begin{array}{l}\text { keep a reflective professional } \\
\text { journal }\end{array}$ & $72 \%$ & $14 \%$ & $12 \%$ \\
\hline $\begin{array}{l}\text { access journal articles in an } \\
\text { online library }\end{array}$ & $62 \%$ & $46 \%$ & $12 \%$ \\
\hline $\begin{array}{l}\text { act as a critical friend' or mentor } \\
\text { online }\end{array}$ & $82 \%$ & $12 \%$ & $6 \%$ \\
\hline $\begin{array}{l}\text { help others learn in an online } \\
\text { group }\end{array}$ & $80 \%$ & $14 \%$ & $6 \%$ \\
\hline $\begin{array}{l}\text { trouble-shoot technical connec- } \\
\text { tion problems }\end{array}$ & $66 \%$ & $26 \%$ \\
\hline access an online module & & \\
\hline
\end{tabular}

TABLE II.

TEACHERS CPD EXPERIENCE PRE-PROGRAMME

\begin{tabular}{|l|l|l|l|}
\hline & Never & Sometimes & Often \\
\hline CPD that was not assessed & $8 \%$ & $40 \%$ & $52 \%$ \\
\hline $\begin{array}{l}\text { Award bearing assessed } \\
\text { CPD courses }\end{array}$ & $54 \%$ & $34 \%$ & $12 \%$ \\
\hline Masters level CPD modules & $52 \%$ & $40 \%$ & $8 \%$ \\
\hline $\begin{array}{l}\text { Face to face contact CPD } \\
\text { courses }\end{array}$ & $4 \%$ & $38 \%$ & $58 \%$ \\
\hline $\begin{array}{l}\text { Paper based distance learning } \\
\text { CPD courses }\end{array}$ & $80 \%$ & $18 \%$ & $2 \%$ \\
\hline $\begin{array}{l}\text { Online distance learning CPD } \\
\text { courses }\end{array}$ & $76 \%$ & $12 \%$ & $12 \%$ \\
\hline $\begin{array}{l}\text { Combined online and } \\
\text { face to face courses }\end{array}$ & $72 \%$ & $24 \%$ & $4 \%$ \\
\hline
\end{tabular}

CPD - Continual Professional Development

the researcher was able to use different data sources to triangulate, validate and crosscheck findings.

The questionnaire, completed around spring of 2013, was comprised of a set of 33 questions including learner experience with the use of information, computer technology (ICT) and previous continual professional development (CPD) experiences, perceived challenges, and helpful factors which contributed to participant's online experiences. The questionnaire items were based on insights gained from review of the literature and piloted initially with 10 volunteers in order to validate the initial pilot research questions. Revisions were made based on the feedback from the sample prior to full implementation. 
The researcher subsequently interviewed participants who volunteered to participate in a follow-up telephone interview. Interviews were conducted to obtain more indepth information in regard to learner perceptions of online learning and to glean any further advice they may have on improvements which might be made on the programme in general and for new online learners in particular. Data from the interviews were used to substantiate and extend results from the questionnaire. The data collection process had ended by mid April 2013.

\section{Data Analysis}

Analysis of the data focused, in the main, on the two areas addressed in the research questions: learners' perceived helpful and motivational components in online learning and learners' perceived challenges in online learning. Organization and analysis of the questionnaire data were completed by using SNAP 9 Professional (software produced by Tidestone Technologies and used to create the online questionnaire). The entire questionnaire data set was entered into the program. Subsequent analysis of the data occurred by identification of specific survey questions and further analysis.

Qualitative data analysis consisted of coding the interview transcripts. A number of strong themes emerged from both questionnaire and interview analysis. Nine (9) were identified suitable for coding. Coding was first completed by the researcher. The researcher then met with one other, compared coding evidence and discussed ideas further in order to reconcile differences and identify final overall themes and patterns.

Themes and patterns were then chosen according to the research questions. Results from the analysis are discussed in the following sections.

\section{FINDINGS}

Findings indicate several trends in overall components perceived as motivational success factors and barriers which confront learners in online learning contexts.

\section{A. Which factors support successful learning in an online environment?}

Findings from this study indicate that the majority of the participants identify the following areas as helpful in their online learning: 1) independence and ownership of working practices, 2) tutor support, 3) meaningful relevant materials, 4) course access and design including helpful time frames and 5) sharing professional practice. (see Table 3) $(\mathrm{n}=50)$.

When asked to put a value to on online learning on a 5 point scale where 5 was excellent participants scored as follows: $5(24 \%), 4(48 \%), 3(24 \%), 2(3 \%)$ and $1(0 \%)$. When asked if they enjoyed online learning $96 \%$ of the participants scored yes.

Participants who were interviewed were asked about using online learning and discussion in their own teaching practices in the future and reported as follows: learning communities could be used for doing homework and assignment tasks from home (24\%), participants saw potential in using such teaching and learning pedagogy through * Glow (21\%), for pupil revision (12\%), 6\% considered online learning and discussions could be easily used for subject specific tasks in science and modern language, use of learning communities was suggested for pupil/teacher
TABLE III.

FACTORS WHICH CREATE SUCCESSFUL ONLINE LEARNING ENVIRONMENTS

\begin{tabular}{|c|c|}
\hline Theme & $\begin{array}{c}\text { Percentage of participants making com- } \\
\text { ment }\end{array}$ \\
\hline $\begin{array}{l}\text { independence } \\
\text { of learning and } \\
\text { ownership of } \\
\text { working prac- } \\
\text { tices }\end{array}$ & $\begin{array}{l}\text { Posting responses to discussions in your } \\
\text { own time }(81 \%) \text {, Flexible working prac- } \\
\text { tices - you can work when you like } \\
(74 \%) \text { Can work at your own pace and } \\
\text { time scale }(33 \%) \text { Accessibility of learning } \\
\text { materials }(33 \%) \text { You don't need time off } \\
\text { work }(12 \%) \text { Free of geographical con- } \\
\text { straints }(12 \%) \text { Suits family life and other } \\
\text { work commitments }(9 \%) \text { No need to get } \\
\text { permission to get out of school }(3 \%)\end{array}$ \\
\hline tutor support & $\begin{array}{l}\text { Feeling well supported by the tutor } \\
(66 \%) \text {, having effective technical support } \\
(42 \%) \text {, Use of automatic response ques- } \\
\text { tions }(30 \%) \text { Support and encouragement } \\
\text { - tutor easy to contact and good quick } \\
\text { feedback given }(24 \%)\end{array}$ \\
\hline $\begin{array}{l}\text { meaningful } \\
\text { relevant materi- } \\
\text { als }\end{array}$ & $\begin{array}{l}\text { Getting a relevant mix of materials which } \\
\text { challenge thinking and support hands on } \\
\text { work in the classroom/school setting } \\
(81 \%) \text {, Good availability of resources } \\
(12 \%) \text { Good mixture and variety of re- } \\
\text { sources }(3 \%)\end{array}$ \\
\hline $\begin{array}{l}\text { course access } \\
\text { and design } \\
\text { including help- } \\
\text { ful time frames }\end{array}$ & $\begin{array}{l}\text { Links to relevant reading information and } \\
\text { the effective use of informative video } \\
\text { clips }(69 \%) \text {, Having a suggested work } \\
\text { schedule }(63 \%) \text { The timing when the } \\
\text { module runs }(51 \%) \text { Easy access to online } \\
\text { site from wherever you want to work } \\
(3 \%)\end{array}$ \\
\hline $\begin{array}{l}\text { and sharing } \\
\text { professional } \\
\text { practice }\end{array}$ & $\begin{array}{l}\text { Peer sharing and feeling part of the group } \\
(57 \%) \text { Finding out how your school } \\
\text { works ( } 48 \%) \text { Social, relationships and } \\
\text { sharing ideas and good practice }(42 \%) \\
\text { Taking part in online discussion }(30 \%) \text {, } \\
\text { Feeling part of the group ( } 30 \%) \text {, Sharing } \\
\text { and communication with others }(3 \%) \text { Can } \\
\text { discuss real life scenarios and share prac- } \\
\text { tice in schools nationally }(3 \%)\end{array}$ \\
\hline
\end{tabular}

online forums $(3 \%)$, as a means to allow pupils to work at their own level (3\%), some interviewees suggested use of online working in the event of staff illness (3\%). 99\% of those interviewed would recommend this way of working to others and $96 \%$ reported that they enjoyed working online.

Additional strengths and helpful factors were identified from analysis of the online questionnaire. Convenience and flexibility were main strengths of online learning indicated in the data. Participants reported that it was helpful not to have to travel into the centre and in fact for some, for example for one student in Grand Canarias and another working in Dubai, travel was totally impossible.

Working from home at a time which suited personal family circumstances and professional teaching preparation and was also valued highly. The ability to complete online module reading, tasks and assignments at anytime 
was another reported strength. In addition participants appreciate being given helpful time frames.

Modules were designed in Blackboard. Reviews of the use of such technologies were mixed by interview participants. Gains were however recognized in professional knowledge and understanding where $84 \%$ of participants agreed or strongly agreed while $79 \%$ agreed or strongly agreed that development of intellectual and professional skills had taken place through online learning and discussion. Participant number 2 suggested that online line learning was lively and interesting 'There was never a dull moment'. They further suggested that they had learned a lot, stating, 'There were always moments of anticipation, eagerness and excitement when I logged on to see what was new - I would recommend it to anyone'. Participant number 11 felt that they had enjoyed working in this way and stated, 'It was motivating and different from anything I had ever done'.

Participant number 1 liked communicating through the discussion board feature. They felt it 'helped them develop confidence about their own thinking, practice and professional writing' and stated 'being able to discuss and read the work of others, both from the cohort and published authors helped me clarify where I am at professionally'.

The ability to post, read, and respond to the thoughts of others at any given time was a plus. Participant number 12 stated 'I learned at my own pace. I had constant access to the views of the rest of the cohort which allowed for reflection before responding and a continual ability to assess how my views fitted with the group or not as the case may be'.

Overall, participants indicated that initially at least, messaging and pace should be driven by the tutor in order to facilitate communication, support confidence with technology and 'speaking' online and for the building of a community. Participant number 8 stated 'We got excellent feedback from the tutor. She was very quick to respond which is vital when you set aside a weekend and then can't get on with a task if stuck and no help is available until a few days have passed'.

\section{B. Which factors create de-motivating barriers or challenges?}

Many participants in this research study reported problems with 1) self motivation, 2) coping with technical problems, 3) professional time constraints, 4) a lack of personal contact and a sense of frustration when certain students did not always contribute to the work of the online community and are expressed in Table 4 above $(n=50)$. Overall, 22\% of questionnaire respondents agreed or strongly agreed with the statement that there were real disadvantages to working online.

One of the biggest challenges reported by study participants focused on dealing with technical problems (27\%). The concern over technical problems was also reflected across most interviews. Participant number 15 commented on their technical problems, stating that participants need to 'be prepared that there are times when you have technical difficulties and you can't really do anything about that'. Technical problems were more significant for some participants than others. This may have been related to initial ICT skills, confidence and expertise. Participant number 6 blamed the 'erratic behaviour of computers at
TABLE IV.

FACTORS WHICH CREATE BARRIERS IN ONLINE LEARNING ENVIRONMENTS

\begin{tabular}{|c|c|}
\hline Theme & $\begin{array}{l}\text { Percentage of participants } \\
\text { making comment }\end{array}$ \\
\hline Self-motivation & $\begin{array}{l}\text { Getting yourself motivated } \\
\text { to switch on the computer } \\
(30 \%) \\
\text { Being able to set your own } \\
\text { pace }(12 \%) \\
\text { Getting distracted }(3 \%)\end{array}$ \\
\hline $\begin{array}{l}\text { Coping with technical } \\
\text { problems }\end{array}$ & $\begin{array}{l}\text { Technical problems, } \\
\text { Blackboard or schools ICT } \\
\text { system not working }(27 \%) \\
\text { Access to computer hard- } \\
\text { ware or broadband }(9 \%) \\
\text { Not having effective tech- } \\
\text { nical support }(9 \%) \\
\text { Participant's computer } \\
\text { skills }(3 \%)\end{array}$ \\
\hline $\begin{array}{l}\text { Professional time con- } \\
\text { straints }\end{array}$ & $\begin{array}{l}\text { Timing when courses run } \\
\text { in the school year }(6 \%) \\
\text { Having to work weekends } \\
(3 \%)\end{array}$ \\
\hline $\begin{array}{l}\text { Lack of personal contact } \\
\text { and a community where } \\
\text { certain students did not } \\
\text { always contribute }\end{array}$ & $\begin{array}{l}\text { Slow tutor responses or } \\
\text { support }(18 \%) \\
\text { Relying on other partici- } \\
\text { pants to keep to the discus- } \\
\text { sion }(6 \%) \\
\text { Lack of communication } \\
\text { from certain participants } \\
(6 \%) \\
\text { Lack of personal contact } \\
(3 \%)\end{array}$ \\
\hline
\end{tabular}

times (or is it the person who works them)'. Participant number 3 suggested that 'technical aspects, equipment and ICT skills were a perhaps a barrier for some'.

Participants who were, in general, less satisfied with online learning as compared to traditional face to face teaching felt a lack of community spirit within the online environment and discussion area and they suggested that frustration felt with those who did not play their part in discussion was a definite challenge for some people on online courses. Participant number 1 stated 'When participants do not contribute to discussion tasks it leads to frustration from those who are waiting to get on or get their comments'. They continued, 'Faceless people, are easier to deal with but it can make the course a bit impersonal.'

The concern over a lack of community was also expressed in the interviews. Interview participants indicated that they felt the formation of a community in an online course could occur if the tutor facilitated this notion to begin with until people had time to bond into effective learning communities and suggested this may be one reason for the lack of self motivation as reported by $30 \%$ of participants interviewed. Participant number 7 commented 'Online learning suits self motivated individuals' 
and participant number 12 suggested 'Without a class to attend there is an issue of motivation.' They continued, 'You are also relying on other students to keep the discussion active'.

\section{DISCUSSION}

This study focused on participant's perceptions of helpful and motivational factors and de-motivating barriers in online learning environments. Issues identified as helpful and hindering in this study were similar to that identified in previous research. For example, 10]. Muilenburgh and Berge (2005) in their factor analytical study outlined evidence of technical and IT skills expertise as well as with that of participant social interaction.

It was clear that participants laid great value on their ability to work independently within set parameters and the accommodation of individual work patterns was noted and appreciated. Participants felt a sense of ownership and independence as online learners, no longer requiring permission to get out of school to attend face to face in-centre modules. Working practices were reported to be built round family and other professional teaching commitments, time and the cost of traveling was negated and participants could work from their home or place of work as required, where ever and at whatever time they wished and individual work patterns were accommodated. Many participants worked predominantly at weekends or during holidays for example.

The importance of tutor support was very apparent in building confidence in the use of technology, allowing participants to express themselves through discussion board messaging and driving and supporting online bonding and the subsequent sharing of professional practice within online learning communities.

Other issues related to tutor and technical support were highlighted as useful. In general these appeared to be related to technological experience and comfort level. In this study, previous experience with the technology may have influenced the participants' perspectives of how useful the technologies were for online learning. Concerns associated with comfort in using the technologies are not insignificant. Researchers in the area of technology integration have long understood this to be a key element in the successful use of technology for learning [12]. Hooper and Riebet (1995). Indeed, previous research related to web-based learning has also indicated the importance of this factor [13]. Hill (2002). How to best facilitate the building of skills and comfort remains a challenge for facilitators and learners. It would appear that the speed of response to learners by the tutor in overtaking computer based problems significantly helped to support participants and may have served to overcome reported issues of lack of self-motivation. Technical problems have long created challenges with the use of technology for learning. Indeed, it is important to minimize the issues as much as possible from the beginning of the learning experience. This has been accomplished in a variety of ways, including providing overviews of the tools used for the module and the issue of simplified tutorial packs to be used by participants to self support in the online learning experience. It is also equally important to help learners understand that problems are going to occur-and most likely at the most inconvenient time [13]. Hill (2002). Facilitators can help ease the stress by letting learners know at the beginning of the course that they understand problems will occur. Learners can help ease their own stress by recognizing that problems can occur and for example making back-up copies to help protect their work.

Although professional time constraints were flagged up as a barrier (time being a precious resource for practicing teachers) there was considerable support for the use of time frames. Participants could thereby check expected progress through module materials and tasks and this would appear to have supported feelings of reassurance. In ability to manage time required for studies was identified by [10] Muilenburg and Berge (2005) and time management was identified as useful for online learning. This study therefore reinforces the importance of time management strategies for assisting with the online learning process. [13]. Hill's (2002) research indicates that implementing strategies such as working at the same time and in the same space can have an impact on the success of the online learning process. She also suggests that a regular schedule be established for engaging in the dialogue that occurs in an online context. According to Hill, by putting into place basic time management strategies, learners can improve their overall online learning experience.

Several other barriers were identified as challenging for online learning. Working alone, lack of community, or angst with those who are perceived not to pull their weight in an online setting is not a new criticism voiced by learners, nor is it a new challenge in the literature.

Research studies have shown the importance of sense of community in participants' learning experiences. For example, in [17]. Rovai's (2002) study, the author studied 314 students who were enrolled in 26 graduate education and leadership online courses taught via Blackboard.com e-learning system. The results of the study indicated a significant relationship between learners' perceived sense of community and perceived cognitive learning. The stronger the online learners' sense of community, the less isolated they felt and the more effective professional sharing can take place. Given that sense of community continues to be an issue indicated as important in this study, such warrants further exploration as well as the creation of processes to enable the connections to occur. It was apparent that the skills of the tutor are paramount here.

Importantly, the relevance of module materials to chalk face practice was flagged up as a motivating factor. Easy access and clearly understandable module design were some of main factors identified as helpful for online learning. Designers have devoted decades of research and development to create models and processes to assist with instruction [14]. Dick et al. (2000); [15]. Smith and Ragan (2000). It is not overly surprising therefore that these factors were brought forward by this study. As stated by [16]. Dempsey and Van Eck (2002), it takes good design to make good online instruction. The challenge that remains is one of examining the current models and processes that exist for face-to-face instruction and see how well they work for online instruction and therefore how they might be adapted to support participant need.

In addition to discussing specific challenges with interviewees and through triangulation with data collected from end of module evaluations, several suggestions for tutors teaching online courses and for prospective online learners were collected. A factor that emerged for all was organization. Organization on the part of the tutor should include establishing goals from the beginning of the 
course, providing explicit directions, providing examples of final summative assessment, and establishing a time frame of clear deadlines. Participants should also work to maintain organization by setting a schedule and making the course web site a part of their daily activities.

Finally, the afore mentioned limitations of this study are to be noted in that the participants in this sample were full time employed, professional teachers who were adult lifelong learners and so findings may not be entirely generalized and applied to student learning groups at Universities and Colleges.

\section{CONCLUSIONS}

The current study offers several general implications for practice and research. There is clearly a need to establish a sense of independence on the part of the learner for online courses. The materials being studied should support a good balance between theory and practical hands on practice within the participant's own setting. Access to online work and speed of support given by the tutor is essential to effective bonding and professional sharing in online learning communities. There should be support not only on the technological aspects of the course, but also on setting expectations for the learners. Furthermore, there is a need to work with learners to assist them in the development of time management strategies. Online courses are dynamic on multiple levels: information is received in a variety of formats and at different times. When learners are accustomed to learning in more static, real-time contexts, this can create significant time management issues. Assisting learners in establishing strategies for managing their time may prove to be useful.

Finally, there is a need to work with learners to assist them with establishing community or feelings of connection in online contexts. Integrating strategies for community building into the design of the course may assist with this effort. Continued research related to community building strategies in a variety of contexts is also needed to enable the advancement of best practices in the dynamic context of the web.

The growth of the Internet and online learning will continue, and as indicated in this study, it will come with challenges. Individuals engaged in an online programme may have different qualities for a successful online environment or elements that they see as barriers to their progress in online working. Each experience will be unique to the individual. As educators and participants become more comfortable and adept at communicating and learning at a distance, it will remain imperative that the best practices associated with these learning environments continue to be explored.

\section{ACKNOWLEDGMENT}

The Author would like to acknowledge the challenging discussion which took place with fellow lecturers at the University of Aberdeen and thank them for their counsel and support.

\section{REFERENCES}

[1] D.W. Hofmann, "Internet-based distance learning in higher education," in Tech Directions, vol 62(1) 2002, pp. 28-32.

[2] M.L. Santovec, "Faculty development," in Distance Education Report, vol 7(2), 2003, p.8.

[3] J. Leonard, and S. Guha, "Education at the crossroads: online teaching and learners' perspectives on distance learning." in Journal of Research on Technology in Education, vol 34(1), 2001, pp. 51-57. http://dx.doi.org/10.1080/15391523.2001.10782333

[4] D.M. Poole, "Student participation in a discussion-oriented online course: a case study." in Journal of Research on Computing in Education, vol 33(2), 2000, pp. 162-177.

[5] A.P. Rovai, "Building classroom community at a distance: A case study" in Educational Technology Research and Development, vol 49(4), 2001, pp.33-48. http://dx.doi.org/10.1007/BF02504946

[6] S. Vonderwell, "An examination of asynchronous communication experiences and perspectives of students in an online course: a case study." in Internet and Higher Education, vol 6, 2003, pp.7790. http://dx.doi.org/10.1016/S1096-7516(02)00164-1

[7] L.A. Petrides, "Web-based technologies for distributed (or distance) learning: Creating learning-centered educational experiences in the higher education classroom." in International Journal of Instructional Media, vol 29 (1), 2002, pp.69-77.

[8] J.E. Chizmar, and M.S. Walbert, "Web-based learning environments guided by principles of good teaching practice." in Journal of Economic Education, 1999, pp. 248-264. http://dx.doi.org/10.1080/00220489909595985

[9] L. Schmum, “Oh, What wonders you will see: Distance education past, present, and future." in Learning and Leading with Technology, vol 30(3), 2002, pp. 6-9, pp. 20-21.

[10] L. Muilenburg, and Z. Berge, (2005). Student barriers to online learning: A factor analytic study. Distance Education vol 26(1), pp. 29-48. http://dx.doi.org/10.1080/01587910500081269

[11] R.H. Woods, "How much communication is enough in online courses? Exploring the relationship between frequency of instructor-initiated personal email and learners' perceptions of and participation in online learning. “ in International Journal of Instructional Media, vol 29(4), 2002, pp. 377-394.

[12] S. Hooper, and L.R. Rieber, "Teaching with technology". In A.C. Orstein (Ed.), Teaching: Theory into practice Allyn and Bacon Boston 1995, pp. 154-170.

[13] J.R. Hill, "Overcoming obstacles and creating connections: community building in web-based learning environments." in Journal of Computing in Higher Education, vol 140, 2002, pp. 67-86. http://dx.doi.org/10.1007/BF02940951

[14] W. Dick, L. Carey, and J.O. Carey, The systematic design of instruction, 5th ed., New York Harper Collins, 2000.

[15] P.L. Smith, and T.J. Ragan, Instructional design. New York. John Wiley and Sons, Inc., 2000.

[16] J.V. Dempsey, and R.N.V. Van Eck, "Instructional design on-line: evolving expectations." In R.A. Reiser \& J.V. Dempsey (Eds.), Trends and issues in instructional design and technology Pearson Education New Jersey 2002, pp. 281-294.

[17] A.P. Rovai, "Sense of community, perceived cognitive learning, and persistence in asynchronous learning networks." in Internet and Higher Education, vol 5, 2002, pp.319-332. http://dx.doi.org/10.1016/S1096-7516(02)00130-6

\section{AUTHORS}

S.M. Paterson lectures at the School of Education, University of Aberdeen, Kings College Campus, Kings Street, Aberdeen, Scotland, UK. AB24 5UA (E-mail: s.m.paterson@abdn.ac.uk)

Submitted 29 April 2014. Published as re-submitted by the author 14 May 2014. 